\title{
Institutional enforced board diversity in sport clubs as trigger of us-them divisions
}

\author{
Michel van Slobbe
}

\section{Introduction}

Over the course of the past two decades, there have been many attempts to bolster diversity in governance bodies, in both the private and the public sector. These attempts have been guided by the general expectation that enhancing diversity will bring about more equity and multivocality, better representation of the people being governed and diverse perspectives which provide better ideas (Callen, Klein \& Tinkelman 2003). Accordingly, recent codes of good governance in sport and related indicators seem to assume that diversity in board compositions leads to better governance per se, e.g. National Sports Governance Observer (Geeraert 2018), Basic Indicators for Better Governance in International Sport (Chappelet $\&$ Mrkonjic 2013), The Principles of Good Governance for Sport and Recreation (Sport + Recreation Alliance 2017) and Conceptual model for the corporate governance of sport (McNamee \& Flemming 2005). These codes of conduct and indicators as institutional products make this claim on the positive outcome of diverse board composition self-evident. Hence, we should ask ourselves the following: Is diversity in board compositions positive a priori and which power dynamics occur when diversity is enforced by institutional interventions? This contribution reflects on these two questions and argues that reform strategies aimed at diversity in board compositions should consider a political perspective to avoid paradoxical effects. It argues that well intended policies aimed at diversity can lead to unintended consequences, namely social exclusion and decreasing policy legitimacy.

This chapter describes and reflects on a reform strategy enforced by the municipality of Utrecht, the Netherlands aimed at the transition from an all-white Dutch board towards an ethnically and gender diverse board of an amateur football club. The case of this local football club represents broader issues that deal with the real and alleged meanings of sport for social integration in the Netherlands and elsewhere as well as with good governance reforms and their meanings (Van Slobbe 2019). In recent years, Dutch policymakers have embraced the idea that sport is both device and locale for promoting an inclusive society. This corresponds to wider-held views about sport as 'the great social leveler' (Donnelly 1996) and about the masculine white 'hegemony' in sport boards (Atkinson 2011). 
Expectations are high concerning sport's potential for bridging social differences and removing inequality. In particular, this is reflected in the desire to achieve greater diversity in sport boards as part of good governance reforms.

Ethnic minorities in the Netherlands, including the Moroccan Dutch, have established their own football clubs as far back as the 1960s. However, current public opinion and policy emphasise the need to create so-called ethnically mixed clubs. Ethnically 'separate' or ethnic-specific clubs are considered undesirable, as they allegedly hinder the social integration of ethnic minority groups into wider Dutch society. Comparable discussions about ethnic minority clubs are found in England about British Asian amateur football clubs (Burdsey 2009). At the same time, many individuals from ethnic minority groups opt for membership of what can be described as 'established' Dutch football clubs. These clubs are becoming increasingly ethnically 'mixed'. For the most part, the board of these clubs remains in the hands of white Dutch men. Hence, in their effort to promote inclusive sport, institutional actors like governments (national and local), sport federations, consultants and researchers encourage and enforce board diversity in sport organisations.

Studies of board structures and composition represent a popular area of corporate governance research and there is still relatively little attention paid to the dynamics of how such groups actually work, or to potential solutions when dynamics break down (Durisin \& Puzone 2009). Considering this gap, the present contribution examines how board members of a sport club enacted an enforced transition towards a diverse board composition and analyses the power dynamics involved.

\section{Argument}

In the endeavour to realise effective boards, accountability to, and engagement with stakeholders, and driving sustainable practices, 'diversity' is incorporated in good governance codes. This institutional process carries the danger of reification, making diversity a naturally, fixed 'thing' and a goal in itself. Sport organisations are increasingly held accountable and will feel compelled to adjust, at least numerically, their board composition. At the same time, we know little about enforced diversity, related power dynamics in the board rooms and the interplay with the organisation as a whole. In this study, power is understood as a dynamic and interdependent social relation, in which individuals and groups to a greater or lesser extent are able to define the social norm and impose their will on others. Dynamics occur when an actor does not abide by his inferior position and seeks improvement. This subsequently endangers the superior position of the other actor or can at least be perceived as such. So, enforcing diversity in the board compositions of sport organisations is not entirely unproblematic and power dynamics will play a role. This raises the question how diversity in real life boardroom situations relates to effectivity, transparency, accountability, engagement and sustainability. To be clear, the present does not question diversity in 
itself. Instead, it argues that reformers should be aware of how shifts in the balance of power, as a result of changing board composition, may lead to competition instead of cooperation.

\section{The sport club board as established-outsider figuration}

In the Netherlands, ethnic minorities increasingly participate in boards of sport organisations, notably in amateur football clubs run by volunteers. These minorities are often considered as 'space invaders', as Puwar (2004) terms it. Sport clubs encounter new contestations from 'outsiders' invading the club's boardroom space and from policies aimed at diversity and inclusive sport. According to Cohen (1985), sport clubs, are symbolically constructed communities of people who share common understandings. Those who belong to the community share the ability to use, interpret and understand the communal symbols. As Cohen argues, people become 'most sensitive' to their own shared meanings and symbols when they encounter 'others' (1985, p. 70). When people feel that the base of their community is undermined as a result of the interactions with 'others', people tend to reinforce the symbolic boundaries of their community (Cheska 1984).

For the analysis of the power dynamics related to the enforced transition towards an ethnically mixed club board, I turned to the concept of 'established and outsiders', as presented by Norbert Elias and John Scotson (Elias \& Scotson 2008). In Elias' established-outsider theory, the concepts of 'mutual dependency' and 'balance of power' play a central role. According to Elias, people are to be understood in their mutual dependency; what he terms, a 'figuration' (Elias 1978). Interdependencies are related to power, which Elias sees as relational and reciprocal, with the more powerful group dependent on the less powerful group and vice versa. The key issue in a figuration is that within such a social network, different valuations are assigned to the separate groups. For Elias, the existing balance of power is a result of the search for the order in which both groups are mutually dependent. In their study of the power relationships between 'established' and 'outsiders' among resident groups, Elias and Scotson found that the longer individuals live in the neighbourhood (what they call 'oldness of association') the more this enables the 'established' to develop greater cohesion relative to the outsiders. This then enables them to monopolise key positions in local associations (Elias \& Scotson 2008; cf. Lake 2011). Consequently, the 'established' are able to define the local rules of the game and reproduce a historically grown position of power. In such a 'figuration', the established group aims at maintaining its position and the 'outsiders' strive to improve their position in the balance of power. According to Elias and Scotson, 'stigmatising' and 'the possession of key positions' appeared to be the main sources of power in the contest between the two resident groups (Elias \& Scotson 2008).

No figuration - whether sport in general or sport club boards in particularare fixed entities with unmovable boundaries. On the contrary, the symbolic understandings and the identities these produce are always contested. Moreover, 
figurations are shaped in the relationships among established members and outsiders and in the relationships between both groups. Following Elias, this contribution conceptualise both sport clubs and their boards as interacting figurations in which members make claims about difference and similarity, and construct divisions between 'us' and 'them'.

\section{The club board as arena}

Understanding institutional influence on established-outsiders relationships in sports club boards as a voluntary setting requires an analysis, in which attention is paid to both formal processes (goal rationality, roles, policy and plans) and the dominant informal processes (personal relationships, preferences and differences of interest). The arena model offers a suitable framework for analysis for this because it can be described in terms of both, process and system (Verweel 1987). Turner (1974) speaks of controversial acts that are fought out in the arena. He defines the arena as "a bounded spatial unit in which precise, visible antagonists, individual or corporate, contend with one another for prizes and/or honor" (1974, p. 132). Turner sees the arena as an explicit framework where people's choices are visible to everyone, people are outspoken and actions have definitive and direct consequences.

Verweel (1987) further elaborated on Turner's arena model for insight into power dynamics in boards and emphasises the invisible governance processes. He defines the political arena as "the dynamic inclusion and exclusion structure, including regulation, which functions as a focal point for the competitive interaction of practices" (ibid, p. 96). As structuring elements of the arena, Verweel distinguishes the arena as the demarcated space of the battle, the positions of the players and parties, the rules of the game (meeting conventions), the weapons and the power relations between the players (Verweel 1987, p. 96). According to Verweel, these elements structure the dynamics in board interactions of the warring parties. The arena model implies, as Elias and Scotson (2008) also indicates with his concept of 'balance of power', a changeable balance of power, which will start negotiations again.

Regarding the power relation with a diversity-enforcing government, it should be noted that vulnerable sport clubs like the football club studied are dependent on municipal support. These clubs tend to follow the institutional expectations and 'go public' instead of staying private (Meijs 1997). Therefore, the government is regarded as the third actor intervening on the power balance of the established-outsider figuration for the purposes of this study.

\section{The case: The making of an ethnically diverse club board}

This chapter emerged from ethnographic research on the enforced transition from an all-white Dutch board towards an ethnically diverse board of an amateur football club. Ethnography, both as an epistemology and as a method, is 
appropriate for trying to grasp interpretations and understanding of complex processes and actions that are characteristic of local settings (Blommaert \& Jie 2010). Lake argues that the relatively autonomous nature and established hierarchical structure of voluntary sport clubs "provide excellent locations for analyzing power relations between members, and how social status and cohesion are emphasised" (2011, p. 9).

During the fieldwork, I collected data through participant observation of naturally occurring events, informal talks and interviews. My role is best described as 'participant-as-observer' (Bryman 2008). That is, during my research I was functioning as a member of the social setting at the football club. For three years, I participated in the club board with an administrative role and was responsible for the membership records and fees, among other things. Members of the football club were informed about my research. The collected data provided insight into the ways through which the board members of the football club interacted and enacted the enforced transition towards an ethnically diverse board.

Before presenting three key incidents in which power dynamics occurred and the balance of power within the board turned, the municipal intervention will be introduced.

\section{The municipal intervention}

In 2008, amateur football club Onder Ons (Among Ourselves) was experiencing financial distress and became dependent on the municipality. The club (founded in 1948), located in an ethnically diverse neighbourhood in the city of Utrecht, was close to bankruptcy, as a result of chaotically fluctuating membership, unstable income and stable fixed costs. In a 'club saving' meeting, a municipal official declared:

Onder Ons is having some troublesome years, for both management and finance and also in organizing the youth section. With the social problems in that specific neighbourhood of the city, with its young dropouts, we see this club as one of the most important clubs. In that part of Utrecht, the need for organised football is enormous... This club is needed there. But at the moment it is organised and managed poorly. Eventually, the club and its management should also represent the population of the neighbourhood.

The meeting resulted in a twofold intervention. The club was given a lifeline, when a substantial part of its debts was paid off by the municipality. Along with this financial assistance, the municipality imposed a condition on the club. The municipality installed two external professionals who, together with two established board members, would form a task force, i.e. a temporary board. The task force assignment involved stabilising the club financially; organising volunteers 
and voluntary management, making a policy plan and nominate a new representative board, at least a Chairman, Secretary and Treasurer.

The municipal intervention was far-reaching and the autonomy of the club decreased. The club was hooked up to a 'municipal drip', as it were. By consenting to the municipal condition, the established board members, were forced to embrace the strategy of 'going public', thus capitalising on the public value ascribed to football club Onder Ons (Meijs 1997).

Both the municipal official and the task force assignment speak of 'representation' by the new diverse board. This purpose fits within a municipal policy aimed at voluntary sport clubs becoming more open, removing membership restrictions and implying an ethnically mixed board, consisting of both 'established' members and the more recently arrived residents of the neighbourhood, the Moroccan Dutch. The premise here is that better representation of different ethnical backgrounds in the club board (comparable to the social composition of the neighbourhood) contributes to a sport environment in which everyone feels at home.

The municipal authority no longer merely formed part of the 'supralocal space' of the club figuration, but also entered and influenced the club's political arena as a third actor enforcing board diversity (Elias \& Scotson 2008). The following three key incidents show how well-intended acts can lead to unintended consequences. As will be seen, the municipal intervention acted as a catalyst for generating a clear us-them division.

\section{Giving a voice to social inequality}

At an annual membership meeting, the 'voice' of the Dutch Moroccan mother of a youth member challenged the position of established members. It turned out to be a prelude to a shift in the balance of power in the recently installed task force.

This first key incident shows the contestation of meanings between the 'established' and the 'outsiders' attached to particular practices and artefacts in the club's organisational culture. It relates specifically to the selling of food and drinks in the club's canteen. In the canteen, a prominent place was reserved for the bar with two beer taps and lightened signboards with beer brands. Shortly after the task force had started its work, the external professionals encountered the 'symbolic boundaries' and 'us-them divisions' of everyday club life. The task force organised a members' meeting to present itself, learn about the club's daily challenges and listen to members. For voluntary sport organisations, the annual members' meeting is an important manifestation of its democratic principle.

At the members' meeting, Fatima, a Moroccan Dutch mother of one of the youth players, raised the issue of selling tea in the club's canteen. At the crowded meeting, she stood up and asked the taskforce: "Can't we buy a cup of tea here?". At that time, tea was not served in the canteen. The tea box had been missing for two weeks and left without replacement by the canteen volunteers. Most of the Moroccan Dutch members were Muslim and did not drink alcohol. Instead, they had coffee or soft drinks. They welcomed the idea of serving tea. Frank, 
the chairman of the task force, promised to talk to the canteen manager, Ari, to arrange for the sale of tea. Two weeks later, after a task force meeting, Frank went to Ari, an active and appreciated volunteer, who fiercely countered the idea and shouted to Frank: "We will not sell tea or halal food in our canteen. Over my dead body!”.

Despite Ari's objections, shortly after this confrontation, the tea box reappeared in the bar and 'Moroccan' tea was served. Furthermore, a Moroccan Dutch canteen volunteer started to sell halal meat. However, these actions were not without resistance. Although several white Dutch members started to appreciate the Moroccan tea, several others questioned the 'unnecessary' investment in an extra halal deep fryer and explicitly doubted whether this would benefit the club financially. The municipal official, when informed about the development, acknowledged the resistance to selling Moroccan tea in the canteen. In an interview, he argued that he and his colleagues were worried about the club's financial situation: "Here [at the club], parents only drink Moroccan tea and that does not generate enough turnover. You just need members who drink beer".

However, it is arguable whether the profit on tea is lower than on beer, knowing that herbs and water for Moroccan tea are very inexpensive. When this was brought into discussion, the official reinforced the notion that selling and drinking beer is an essential component of football culture-the third half of the match'-and would therefore be an unquestionable source of income for Onder Ons. At the club, the issues of alcohol and halal food did not articulate religious differences, but it marked the Moroccan Dutch members as outsiders.

By standing up publicly and asking about the tea, Fatima gave voice to a feeling of social inequality and uneven power relations shared by other Moroccan Dutch members at the club. Through her act, she explicitly claimed a part of the canteen's space. The beer taps, the painting on the wall, the photos of white Dutch teams and the possession of key positions in the canteen symbolise the 'oldness of association' of the white Dutch members. The historically grown position of power gave them the opportunity to decide about the food and drinks in the canteen. In line with Cohen's (1985) arguments, the white Dutch members became 'most sensitive' to their own shared meanings of drinking beer when they encountered Moroccan Dutch who abstained from drinking alcohol and preferred to drink tea. The attendance of many Moroccan Dutch members at the membership meeting and the task force chairman's promise to arrange the selling of tea symbolised a change at the club; arguably, they represented a shift in power. Both Fatima's question and Ari's fierce reaction shows mutual dependency and articulated an us-them division, between the tea drinking 'outsiders' and the beer drinking 'established' members.

\section{The candidacy of Fatima for a board position}

The second key incident concerns the internal resistance by task force members towards the candidacy of Fatima for the new mixed board. In the second half 
of the season 2008-9, Fatima presented herself as a candidate for treasurer in the new 'representative' board that was to be installed as part of the task force's mission. She had financial experience as a member of the youth board, worked as a financial assistant for a bank and studied Financial Management. Fatima, then 43 years old, raised and educated in the Netherlands and recently divorced, lived with her only son of nine years old, in an apartment facing the club. However, two established members of the task force resisted her candidacy. At a board meeting they argued that Fatima was unable to commit herself to the club in the long term. They portrayed Fatima as an opportunistic person. Task force member Henk, for instance, argued: "Fatima will certainly leave the club when her son is accepted by another club. Besides, she is not willing to commit herself for three years".

Fatima's candidacy stimulated other Moroccan Dutch members and parents to become more involved with the club. More parents entered the canteen, they became members and players in senior teams and they took on voluntary work. The involvement of Moroccan Dutch volunteers also led to the refurbishment of the canteen. Even a few of the old team photos were replaced by photos of the current mixed youth teams. Actions such as these suggest that the 'culture' of the club was changing. However, task force member Henk wrote an email in which he expressed his unease about the developments at the club (i.e. the changing power relations). He accused Fatima of being part of a 'coup', in which she tried to convince Aziz, another Moroccan Dutch member, to stand as a candidate for the board as well: "(...) a secret talk between Aziz and Fatima (...) looks like a conspiracy to take over the club, from which I would like to distance myself".

At a subsequent task force meeting, Henk insisted on looking for other candidates for the new board. He threatened to leave the task force if others decided to support the candidacy of Fatima. In order to ensure Fatima was not elected, Henk also stood candidate for treasurer, under the condition that he would not have any formal board responsibilities. In a private conversation between task force members and the intended new chairman, Martin, it was decided that Fatima should be advised not to nominate herself. Task force chairman Frank was tasked with advising her of this, arguing that she was unable to commit herself for three years. A few days later Fatima told one of the members that she had had a meeting with Frank in which he had discouraged her nomination. She was disappointed, but informed the task force that she still intended to pursue her nomination arguing that "there are enough members who support me".

Henk and other club members argued that they doubted Fatima's commitment to the club. Although she had been a volunteer for four years, the interactions demonstrate that she was still considered an 'outsider'. Fatima, who had expressed her willingness to work for the club, encountered a negative attitude, while Henk, unwilling to take full responsibility, did not encounter any resistance. Henk's petitioning was an attempt to stigmatise Fatima. Like the act of resistance by Ari, described in the first incident, Henk also gave voice to a sense of community 'loss'. This illustrates how, when the transition unfolded, the established position 
of the white male Dutch members and their 'symbolic boundaries' were at stake (Cheska 1984).

In June 2008, notwithstanding the resistance by the 'established' members (using stigmatising efforts as well as their key positions), both Fatima and Aziz were democratically elected by the majority of the members as new board members. Together with one white Dutch established member and an externally experienced white Dutch club manager as the new chairman, they formed the new ethnically mixed board of Onder Ons. From outside, the intervention seemed to have been a success. However, along with the board transition, the club's power balance had changed. This was not without consequences, which are discussed in the final key incident.

\section{The exclusion of the last remaining all-white Dutch team}

The name of the club works illustratively in this case. 'Onder Ons' (Among Ourselves) refers to Dutch ideas of familiarity, of being together in a friendly, intimate and safe atmosphere. These ideas were expressed on the club's website: "Onder Ons is a small, intimate and cozy football club where you can always enter the canteen and coffee is always ready". However, the phrase 'onder ons' also indicates a clique that excludes others. In 2010, two senior teams were playing in the regional football league. Onder Ons I started that year with predominantly Moroccan Dutch players and Onder Ons II was the only remaining all-white Dutch team. The latter consisted mainly of established players who were children of elder members. In a meeting with the new mixed board, the potential new coach for the 'established' team declared: "I do not want to desert these lads". As a former player, trainer and board member, he was a renowned club member. At the end of the meeting, he reiterated that he was willing to take up the coaching position, but under the condition of receiving improved support from the club's board. Somewhat surprisingly, he then blatantly expressed his disdain for the 'outsiders' and the (not present) new board member Aziz when he emphasised: "And I am not communicating with that Moroccan, only with you guys".

The new chairman, Martin, reacted with surprise: "You mean Aziz?". The coach confirmed non-verbally and the chairman failed to show his disapproval subsequently. When Aziz heard about the tacit agreement with the coach, a major conflict in the new board unfolded. Comments and enactment such as these, though not representative of all the respondents, do demonstrate the inveterate and institutionalised 'us' and 'them' dynamic within the club and its board. During the season, six of the players of the 'established' team lost their jobs in construction work due to the economic crisis. They stopped paying their membership fees and, moreover, grew very agitated: "Onder Ons is not the club it used to be". After several quarrels with players and fans of opposing (also white Dutch) teams, the Dutch Football Association fined the club and banned the players involved. Finally, the club board forced the second team to leave the league. Its players and other club members reacted angrily and planned to go to another club. 
Though it was a board decision, the opinions in the board differed strongly, and dissensus and ongoing conflict finally led to the breakup of the newly installed mixed board.

When the municipal official was informed about the potential exit of the team and the breakup of the recently installed mixed club board, he was certainly not amused, as he saw the potential for 'white flight' across the club. Indeed, as expected, as white players of Onder Ons II left the club, so too did most of the remaining white Dutch members and volunteers. Despite the club's financial betterment, its increasing youth membership, the participation of Moroccan Dutch parents and the representative board members, the municipal official seemed to conclude that the intervention had failed.

The final key incident shows how the balance of power in the football club and in its board had turned. The domination of the established club's culture did not prevent the exclusion of the white Dutch team and white board members. The 'oldness of association', as the predominant source of power of the 'established', no longer connected to the positions in the club's board.

\section{Conclusion}

The three key incidents demonstrate how the board of an amateur football club functioned as a political arena after a municipal intervention. In the club board of Onder Ons both established members and newcomers strived to maintain and gain key positions to validate themselves and the member groups they represent. The board meetings and members' meeting functioned as the demarcated spaces of the battle between established members and outsiders with changing positions of 'outsiders' Fatima, Aziz and volunteers. The rules of the game (majority votes), 'stigmatising' and 'key positions' were used as weapons during the transition (Verweel 1987). We return to the two questions raised at the beginning of this chapter: Is diversity in board compositions positive a priori and which social dynamics occur when diversity is enforced by institutional interventions? The following can be concluded.

Based on the findings, I argue that the enforced transition towards an ethnically diverse board led to a shift in the balance of power in the club board and in the club as a whole. 'Parachuted' by the municipality and by means of the task force and its assignment, the external professionals changed the interdependencies and provided the outsiders with formal positions that gave them the opportunity to break through the existing dominant informal order. The relations within the task force became increasingly strained leading to an increase in mutual stigmatisation. The positions of the outsiders in the board improved and the positions of the established members grew feeble. The balance of power tipped and ultimately, no ethnically mixed board emerged with all key positions ending up in the hands of the former outsiders. As a result, the formerly established board members no longer felt at home and left the club amid conflict and a feeling of dissatisfaction. 
According to Elias, the core problem in a social figuration is an unequal balance of power and the tensions embedded therein (Elias \& Scotson 2008). Changes in interdependent relationships of individuals lead to power shifts and imbalance. The balance may shift from one end to the other from a seemingly stable equilibrium and the more equitable the positions of groups in the balance of power, the greater the tensions will be. The case Onder Ons shows how an institutional intervention aimed at board diversity acts on this local balance of power and leads to unintended power dynamics and exclusion. The municipal intervention triggered us-them divisions that impede the process of establishing an effective, creative, transparent and sustainable club board. When an ethnically diverse board was eventually installed, the us-them divisions continued to exist.

I conclude that apparent equity in terms of shared participation in the club board does not necessarily lead to bridging ethnic differences. Instead, us-them divisions may lead to mutual stigmatisation and finally, exclusion of members. Despite this, diversity in board compositions ideally brings about more social equity, better representation, more creativity and effectiveness as assumed in good governance codes.

In conclusion, the municipal intervention at football club Onder Ons did contribute to the survival of an amateur football club in the neighbourhood, but unintentionally did not improve board diversity. This highlights a policy paradox, which results from the lack of insight into the power dynamics between members in an established-outsider figuration. In addition, the government ambition to achieve more board diversity, in fact, led to an increase in tensions, because "the need and the ambition to achieve self-esteem is expressed in a universal tendency to increase the value of the individual group, at the expense of that of other groups" (Elias \& Scotson 2008). From a power perspective, 'social equilibrium' has another meaning than is often assumed in the diversity paradigm. Ethnic equity cannot simply be achieved by changes in the formal positions at the board level, as this would neglect the informal day-to-day processes in sport organisations and power dynamics that are related to individual position improvement as well as to position preservation. The numerical representation of ethnic minority groups in sport boards does not necessarily mean the acceptance and integration of outsiders, especially when board positions are concerned. Outside interventions which aim at establishing diversity and equity between groups may result in a situation in which the players change, but the game remains the same.

Reform strategies aiming at inclusive sport and diversity in board compositions need a political (established-outsiders) perspective to avoid paradoxical effects, such as social exclusion and related decreasing policy legitimacy. Governments, sport federations, consultants, researchers and other institutional actors should consider the impact of their interventions on the dynamic balances of power in organisational boards. Contemporary board members of sport organisations should consider the impact of enforced diversity in their boardroom. They should be aware of their interdependent relationships, the respective superior and inferior 
positions of the established and the newcomers. Ultimately, they should avoid either becoming outsiders.

Intervening in the social composition of sport governance can have the unintended effect of triggering us-them divisions and deteriorating social relations. In such boardroom circumstances, equity and multivocality are difficult to realise. Further research is needed to understand the power dynamics in different board compositions and contexts, the extent to which voluntary, nonprofit differs from a profit-based organisational context and ways in which social divisions (education, ethnicity, gender, age, income) work differently in board dynamics.

The case presented in this chapter shows a municipal reform strategy which enforced board diversity externally. It would be conducive to this discussion to learn how the power dynamics develop in a diverse board that is constituted according to the needs of diverse club member groups. Would it be possible for a diverse board to create any kind of 'Onder Ons'? What are the enabling and constraining factors? And what can policy makers and intervening actors learn from it? Research that seeks answers to these and related questions would make a valuable contribution to finding ways how to better achieve the intended outcomes while avoiding negative ones.

\section{References}

Atkinson, M 2011, Deconstructing Men and Masculinities, Oxford University Press, Toronto.

Blommaert, J \& Jie, D (eds) 2010, Ethnographic Fieldwork, Multilingual Matters, Bristol. doi:10.21832/9781847692962

Bryman, A 2008, Of Methods and Methodology, Qualitative Research in Organizations and Management: An International Journal, vol. 3, pp. 159-68. doi:10.1108/ 17465640810900568

Burdsey, D 2009, “Forgotten Fields"? Centralizing the Experiences of Minority Ethnic Men's Football Clubs in England', Soccer and Society, vol. 10, no. 6, pp. 704-21. doi:10.1080/14660970903239925

Callen, JL, Klein, A \& Tinkelman, D 2003, 'Board Composition, Boards and Organizational Efficiency: The Case of Nonprofits', Nonprofit and Voluntary Sector Quarterly, vol. 32, no 4, pp. 493-520. doi:10.1177/0899764003257462

Chappelet, JL \& Mrkonjic, M 2013, Basic Indicators for Better Governance in International Sport (BIBGIS): An Assessment Tool for International Sport Governing Bodies, IDHEAP, Lausanne.

Cheska, A 1984, 'Sport as Ethnic Boundary Maintenance: A Case of the American Indian', International Review for the Sociology of Sport, vol. 19, no. 3-4, pp. 241-57. doi: $10.1177 / 101269028401900304$

Cohen, A 1985, The Symbolic Construction of Community, Tavistock, London. doi: $10.4324 / 9780203323373$

Donnelly, P 1996, 'Approaches to Social Inequality in the Sociology of Sport', Quest, vol. 48, no. 2, pp. 221-42. doi:10.1080/00336297.1996.10484192

Durisin, B \& Puzone, F 2009, 'Maturation of Corporate Governance Research, 1993-2007: An Assessment', Corporate Governance: An International Review, vol. 17, no. 3, pp. 266-91. doi:10.1111/j.1467-8683.2009.00739.x 
Elias, N 1978, What Is Sociology?, Hutchinson, London.

Elias, N \& Scotson, JL 2008, 'The Established and the Outsiders' in C Wouters (eds), The Collected Works of Norbert Elias, Volume 4, UCD Press, Dublin.

Geeraert, A 2018, National Sports Governance Observer. Indicators and Instructions for Assessing Good Governance in National Sports Federations, Play the game/Danish Institute for Sports Studies, Aarhus.

Lake, R 2011, “They Treat Me Like I'm Scum”: Social Exclusion and Established-Outsider Relations in a British Tennis Club', International Review for the Sociology of Sport, vol. 48, no. 1, pp. 112-28. doi:10.1177/1012690211424523

McNamee, M \& Flemming, S 2005, 'The Ethics of Corporate Governance in Sport: Theory, Method, and Operationalization', in D Kluka (eds), Aspects of Sport Governance, Meyer \& Meyer Sport, Oxford, pp. 153-67.

Meijs, LC 1997, Management van Vrijwilligersorganisaties, Dissertation, Erasmus Universiteit, Rotterdam; NOV Publikatie, Utrecht.

Puwar, N 2004, Space Invaders: Race, Gender and Bodies Out of Place, Berg, Oxford.

Sport + Recreation Alliance 2017, 'The Principles of Good Governance for Sport and Recreation.' Sport + Recreation Alliance, London.

Turner, V 1974, Dramas, Fields and Metaphors, Cornell University Press, Ithaca, NY.

Van Slobbe, M 2019, Among Ourselves. Dynamics in established-outsider relations at a sports club with the government as third actor, Dissertation, Parthenon Publishing House, Almere.

Verweel, P 1987, Universiteit: verandering en planning. Een ideologisch-antropologische studie, Dissertation, Universiteit Utrecht, Utrecht. 